\title{
COMMENTS
}

\section{PROCEDURES TO CHALLENGE THE PROCESS OF ADMINISTRATIVE AGENCIES}

The process of an administrative agency has been said not to be open to judicial review until the agency seeks judicial enforcement of its summons or subpoena. 1 This view follows from the belief that the process of an administrative agency is not self-enforcing, ${ }^{2}$ since the agency itself is without power to compel compliance with its subpoena by threat of citation for civil or criminal contempt. 3 It is thought that if the subpoenaed witness refuses to appear and to testify or to produce evidence demanded of him, and the agency wishes to compel the witness' compliance with its process, it must petition the courts for an order directing compliance. ${ }^{4}$ The Federal Aviation Act of 1958,5 for example, provides that the Civil Aeronautics Board may issue subpoenas compelling attendance at investigations ${ }^{6}$ made pursuant to the Act

I See FPC v. Metropolitan Edison Co., 304 U.S. 375 (1938); FTC v. Claire Furnace Co., 274 U.S. 160 (1927); FTC v. Maynard Coal Co., 22 F.2d 873 (D.C. Cir. 1927); Fleming v. Arsenal Bldg. Corp., 38 F. Supp. 675 (S.D.N.Y. 1940).

2 ICC v. Brimson, 154 U.S. 447, 485 (1894); E.I. du Pont de Nemours \& Co. v. Boland, 85 F.2d 12 (2d Cir. 1936).

3 The view taken in ICC v. Brimson, supra note 2, is that the power to punish for contempt is purely judicial. For comment on the Brimson view, see 1 Davis, ADMINISTRATIVE LAw TREATISE \$ 3.11 (1958) [hereinafter cited as Davis]; Note, 35 Colum. L. Rev. 578 (1935); Comment, 71 HARv. L. REv. 1541 (1958). McGrain v. Daughterty, 273 U.S. 135 (1927), holding that legislative bodies may punish for contempt partially undercuts this position, but that case rests in part on the historic practice of legislatures. Indeed some state agencies may punish for contempt. See 1 Davis $\$ 3.11 ; 3$ Loss, Securrties Regulation 1963 n.57 (1961).

4 E.g., (FTC) 38 Stat. 722 (1914), 15 U.S.C. $\$ 49$ (1958); (SEC) 48 Stat. 899 (1934), 15 U.S.C. \& 78u(c) (1958); (FPC) 49 Stat. 856 (1935), 16 U.S.C. \$ 825f(c) (1958); (Tariff Comm'n) 46 Stat. 699 (1930), 19 U.S.C. \$1333 (1958); (IRS) INT. REV. CODE OF 1954 \$ 7604(a); (NLRB) 62 Stat. 991 (1948), 29 U.S.C. \$161 (1958); (VA) 38 U.S.C. $\$ 3313$ (1958); (AEC) 68 Stat. 959 (1954), 42 U.S.C. \$2281 (1958); (FMC) 64 Stat. 1274, 1277 (1950), 46 U.S.C. $\S \S 826,828$ (1958); (FCC) 75 Stat. 422 (1961), 47 U.S.C. $\S \S 409$ (f), (g) (1962); (ICC) 62 Stat. 909 (1948), 49 U.S.C. $§ \S 12(2)$, (3) (1958); (FAA) 72 Stat. 792 (1958), 49 U.S.C. $\$ 1484$ (1958). In addition, the IRS has the power to seek "an attachment against [the recalcitrant witness] as for contempt...." INT. Rev. CODE OF 1954 \$ 7604(b). This provision is generally treated as a means of seeking a judicial enforcement order and does not dictate an automatic penalty; see Brody v. United States, 243 F.2d 378 (1st Cir.), cert. denied, 354 U.S. 923 (1957); Sale v. United States, 228 F.2d 682 (8th Cir. 1956). But compare In re Wolrich, 84 F. Supp. 481, 482 (S.D.N.Y. 1949) (dictum). See text at note 43 infra.

572 Stat. 737-806 (1958), 49 U.S.C. \$§ 1301-1542 (1958).

672 Stat. 792 (1958), 49 U.S.C. $\$ 1484$ (b) (1958). Though most agencies have at least this power, a few-e.g., Patent Office, 35 U.S.C. $\$ 24$ (1958), and the Board of Arbitration under the Railway Labor Act, 48 Stat. 1197 (1934), 45 U.S.C. § 157(3)(b) (1958)-are empowered only to seek issuance of subpoenas by the clerk of the district court. 
and that, in case of disobedience to its subpoena, the Board may seek the aid of the courts. 7 "Any court of the United States ... may, in case of contumacy or refusal to obey a subpoena issued to any person, issue an order requiring such person to appear before the Board .... and any failure to obey such order of the court may be punished by such court as a contempt thereof."'8 Before any order of the court will issue compelling complete or partial compliance with the demands of the agency, there is a quite limited review of the agency process. ${ }^{9}$ If the recipient continues in default and the court, on either its own motion or the agency's petition for enforcement of the first court order, 10 orders the witness to show cause why he should not be held in contempt, there is further review in a proceeding in which there is a heavy burden of proof upon the government. 11 No witness is compelled to comply with the

772 Stat. 792 (1958), 49 U.S.C. $\$ 1484$ (c) (1958).

872 Stat. 792 (1958), 49 U.S.C. \$ 1484(d) (1958).

9 Following Oklahoma Press Publishing Co. v. Walling, 327 U.S. 186 (1946), and Endicott Johnson Corp. v. Perkins, 317 U.S. 501 (1943), the courts have narrowed the scope of adjudication and allowed broad discovery powers upon a showing that the respondent's activities are within the agency's jurisdiction under its enabling act. It is not necessary to show that there is a complaint before the agency pursuant to which investigation is made or that the agency has probable cause to believe that there has been a violation of the law or its rules. See 1 Davis $\$ 3.12$; Comment, supra note 3.

${ }^{10}$ The statutes provide only that in case of contumacy the court may enforce its order. Apparently the usual procedure is for the agency to petition for enforcement. Comment, supra note 3, at 1543. In some cases, at least, the application takes the form of a petition for an attachment for contempt. Sale v. United States, 228 F.2d 682 (8th Cir. 1956); Brungger v. Smith, 49 Fed. 124 (1st Cir. 1892).

11 Kansas City Power \& Light Co. v. NLRB, 137 F.2d 77 (8th Cir. 1943). Because of the broadening of the subpoena power of administrative agencies, see note 9 , supra, courts have become increasingly cursory in examining the validity of subpoenas when issuing judicial orders, and only demands burdensome on their face are usually invalidated at that stage. Indeed, the decision in CAB v. Hermann, 353 U.S. 322 (1957), allowed denial of a hearing at the first stage of enforcement where the court used an agency complaint as a standard in assessing validity. Thus as a practical matter, contempt proceedings may afford the respondent his first judicial hearing on the merits as to the validity of the subpoena-a development difficult to reconcile with the court's concern in Application of Colton, 291 F.2d 487 (2d Cir. 1961), over the "Draconianism" of the threat of criminal proceedings without review. The courts may feel that "because the consequences of enforcement of an order may be more drastic to a respondent than those of enforcement of a subpoena, and because orders come at the end rather than at the beginning of the administrative process ...." (Comment, supra note 13, at 1544), denial of prior review of agency subpoenas does not raise significant constitutional questions. However, review of the validity of the subpoena at some stage, even if only by way of defense in criminal proceedings, would seem constitutionally requisite. Though the Supreme Court has sometimes denied that review is requisite where the government action at issue is non-coercive in its effect upon the complaining individual, see 4 DAVIs $\$ 28.19$; Hart, The Power of Congress to Limit the Jurisdiction of the Federal Courts: An Exercise in Dialectic, 66 HARv. L. Rev. 1362, 1383-87 (1953), it has not done so where coercive action is at issue. Perhaps the most extreme position limiting review in such cases was that taken by the three dissenters in Estep v. United States, 327 U.S. 114, 134, 144 (1946), who regarded habeas corpus after conviction as adequate review, thus taking action which, in Professor Hart's words, "turns an ultimate safeguard of law into an excuse for its violation." Hart, supra, at 1382. But the cases in which the Court 
agency summons or subpoena or is held in contempt for his refusal to comply without some judicial determination of the merit of any of his objections to the legal sufficiency of the process. 12

However, courts denying review until an agency seeks a judicial enforcement order have not seriously dealt with the fact that it may be criminal per se to fail to comply with the process of an administrative agency. ${ }^{13}$ The Federal Aviation Act of 1958 provides, for example, that "any person who shall neglect or refuse to attend and testify, or to answer any lawful inquiry, or to produce books, papers, or documents, if in his power to do so, in obedience to the subpoena or lawful requirement of the Board or Administrator, shall be guilty of a misdemeanor and, upon conviction thereof, shall be subject to a fine of not less than $\$ 100$. nor more than $\$ 5000$., or imprisonment for not more than one year or both."14 Furthermore, the agency may seek the imposition of these criminal sanctions even where the witness' noncompliance is based on a good-faith doubt as to the validity of the agency subpoena ${ }^{15}$ and even though the witness has fully complied with the court order ${ }^{16}$ issued after initial violation and thus would not be subject to citation for civil contempt.17 Indeed, the agency may well be able to seek the imposition of these sanctions without even seeking judicial enforcement of the subpoena.18

has supplied review where none has been provided by statute, see 4 DAvIs $\S 28.18$, adequately support Professor Hart's generalization that "so long at least as Congress feels impelled to invoke the assistance of courts, the supremacy of law in their decisions is assured," at least where rights have not been waived by the parties. Hart, supra, at 1388; cf. 4 DAvs 97.

12 See FTC v. Claire Furnace Co., 274 U.S. 160 (1927); Soja v. Davis, 303 F.2d 601 (7th Cir.), cert. granted, 371 U.S. 810 (1962); E. I. du Pont de Nemours v. Boland, 85 F.2d 12 (2d Cir. 1936); FTC v. Maynard Coal Co., 22 F.2d 873 (D.C. Cir. 1927); FTC v. Waltham Watch Co., 169 F. Supp. 614 (S.D.N.Y. 1959); Caplis v. Helvering, 4 F. Supp. 181 (E.D.N.Y. 1933).

13 E.g., (FTC) 38 Stat. 723 (1914), 15 U.S.C. $\$ 50$ (1958); (SEC) 48 Stat. 899 (1934), 15 U.S.C. \$ 78u(c) (1958); (FPC) 49 Stat. 856 (1935), 16 U.S.C. \$ 825f(c) (1960); (IRS) INT. Rev. CoDe of $1954 \$ 7210$; (NLRB) 61 Stat. 151 (1947), 29 U.S.C. \$ 162 (1958); (Railway Retirement Board) 50 Stat. 316 (1937), 45 U.S.C. $\$ 228 \mathrm{~m}$ (1958). See Eclipse Sleep Prod. v. FTC, Trade REg. REP. I 70,480 (D. Mass. Sept. 24, 1962) where Wyzanski, J., confidently asserts that "failure to produce a document or to give evidence before such an order [court order requiring compliance with FTC subpoena] is issued does not constitute a crime."

1472 Stat. 785 (1958), 49 U.S.C. $\$ 1472$ (g) (1958). This provision differs from similar provisions of other agencies in that some provide that the criminal noncompliance must be "willful" (e.g., FPC, NLRB, Railroad Retirement Board) or "without just cause" (e.g., SEC). See statutes cited note 13 supra.

15 St. Regis Paper Co. v. United States, 368 U.S. 208 (1961); United States v. Clyde S.S. Co., 36 F.2d 691 (2d Cir. 1929).

16 United States v. Clyde S.S. Co., supra note 15; United States v. National Biscuit Co., 25 F. Supp. 329 (S.D.N.Y. 1938).

17 See Penfield Co. v. SEC, 330 U.S. 585 (1947).

18 Application of Colton, 291 F.2d 487 (2d Cir. 1961); United States v. Becker, 259 F.2d 869 (2d Cir. 1958), cert. denied, 358 U.S. 929 (1959). Such action, however, might raise serious questions about the function of the direct penalties and squarely raise the issue of the principle of Ex parte Young, 209 U.S. 123 (1908). See text at notes 24-27 infra. 
Under conventional doctrine, the subpoenaed witness can challenge the agency process only at the risk of severe criminal sanctions, for only by refusing to comply with the subpoena and thereby forcing the agency to seek judicial enforcement of its process may he bring his objections before the court. Does this lack of provision for review prior to violation constitute a denial of due process to the defaulting witness? A significant recent decision of the Second Circuit 19 indicates that it does. ${ }^{20}$

In Application of Colton, 21 the Second Circuit held that a district court had jurisdiction to entertain a motion to vacate a summons 22 issued by the Internal Revenue Service and that the district court's decision is final and appealable.23

19 Application of Colton, supra note 18. In In re Turner, 309 F.2d 69 (2d Cir. 1962), the court noted that the government complained of long delays in its investigations as a consequence of the Colton holding and declared also that "although we do not now perceive any reason to doubt the correctness of the Colton decision, we are of course ready, in this instance as in others, to reexamine a holding on a matter of such public importance if the government deems that any relevant considerations were overlooked." Id. at 72.

${ }^{20}$ Application of Colton, 291 F.2d 487 (2d Cir. 1961), 75 HARv. L. Rev. 1222 (1962).

21291 F.2d 487 (2d Cir. 1961).

22 A district court followed Colton in Application of Howard, 210 F. Supp. 301 (W.D. $\mathrm{Pa} .1962)$, in an opinion devoted more to singing the praises of the Colton court than to legal analysis. Contra, Reisman v. Caplin, No. 16690, D.C. Cir., Feb. 7, 1963. Jurisdiction is said to lie in the district courts under 28 U.S.C. $\$ 1340$ (1958): "The district courts shall have original jurisdiction of any civil action arising under any Act of Congress providing for any internal revenue. ..." In re Turner, 309 F.2d 69 (2d Cir. 1962). But there is no provision in the INT. Rev. CODE OF 1954 for motions to modify or vacate summonses. Application of Colton, supra note 21, at 489 . See also Flemming v. Arsenal Bldg. Corp., 38 F. Supp. 675 (S.D.N.Y. 1940). However, even if jurisdiction could, for unnamed reasons, be said to exist under the statute, other courts have refused to invoke jurisdiction and have denied similar motions, Sale v. United States, 228 F.2d 682 (8th Cir. 1956) (possibly distinguishable on the ground that motion was not made until commencement of enforcement proceedings), or denied that a claim of privilege even affords basis for a motion to quash a summons in the nature of a subpoena ad testificandum or duces tecum. Application of Burr, $171 \mathrm{~F}$. Supp. 448 (S.D.N.Y. 1959).

${ }^{23}$ The court argued that since the motion to quash here is a device to obtain judicial determination of the validity of the IRS summons without the risk of sanctions for noncompliance under $\$ 7210$ of the INr. REv. CODE OF 1954, its denial is like the dismissal of a complaint. But Soja v. Davis, 303 F.2d 601 (7th Cir. 1962), cert. granted, 371 U.S. 810 (1962), held that the issuance of a writ of attachment as a means of judicial enforcement pursuant to $\S 7604$ was interlocutory and not appealable as it did not conclude the proceedings. See note 4 supra, note 49 infra. The Seventh Circuit's decision as to appealability of attachment orders seems questionable, even when viewed in the light of Cobbledick v. United States, 309 U.S. 323 (1940), on which it purported to rely. The Cobbledick case involved an appeal from an order declining to quash a grand jury subpoena. Review was denied, the court distinguishing cases holding that judicial orders enforcing ICC subpoenas were appealable. The court did not rely on the Soja distinction between motions to quash and contempt attachments on the one hand and enforcement orders on the other. Rather it noted that denial of finality to a lower court order "is a phase of the distribution of authority within the judicial hierarchy. But a proceeding like that under... the Interstate Commerce Act may be deemed self-contained ... there is not, as in the case of a grand jury or trial, any further judicial inquiry which would be halted were the offending witness permitted to appeal." Id. at 330. 
In that case, a summoned attorney objected that compulsory production of data demanded by the IRS relating to the filing of his clients' income tax returns would constitute a violation of the attorney-client privilege. 24 Noncompliance with the IRS summons might have subjected the attorney to criminal sanctions under section 7210 of the Internal Revenue Code. The court maintained that this provision is "much more drastic than the usual provisions as to subpoenas by administrative agencies. ..."25 and thus requires application of the principle of Ex parte Young 26 and Oklahoma Operating Co. v. Love. 27 The court noted, however, that "if the statutory scheme were like that for enforcement of subpoenas of such agencies as the Interstate Commerce Commission ... or the Civil Aeronautics Board... there would be merit in the government's position that courts ought not intervene at so early a stage. ..."28 Under the court's view of the latter statutes, no penalty could attach for noncompliance until compliance had been judicially ordered. In Colton, consideration of the motion to vacate was a device to afford judicial determination of the validity of the summons before risk of penalty for noncompliance attached. 29

The decision seems grounded expressly on a constitutional principle;30 and if prior review is not constitutionally required or provided by statute, the courts are without jurisdiction to review.31 Even if review is required, of

24 The case did not go to the merits of the attorney's objections but only to his opportunity to offer them without risk of sanction. The trial court subsequently denied the motion to vacate and partially granted the government petition for judicial enforcement of the second summons pursuant to INT. REv. CODE OF $1954 \$ \$ 7602(\mathrm{~b}), 7604$. In re Colton, 201 F. Supp. 13 (S.D.N.Y. 1961), aff'd sub nom. Colton v. United States, 306 F.2d 633 (2d Cir. 1962).

25291 F.2d at 489. But see Reisman v. Caplin, No. 16690, pp. 6-7, D.C. Cir., Feb. 7, 1963.

26209 U.S. 123 (1908). $\quad 27252$ U.S. 331 (1920). $\quad 28291$ F.2d at 490.

$29 \mathrm{Id}$. at 491 . An action for a declaratory judgment would thus seem more appropriate. See Borchard, Challenging "Penal" Statutes by Declaratory Action, 52 YALE L.J. 445 (1943). The court is silent as to any requirement that the petitioner request the agency to quash the subpoena. Cf. FTC v. Waltham Watch Co., 169 F. Supp. 614 (S.D.N.Y. 1959). On the unwillingness of courts to supply extra-statutory review where administrative remedies have not been pursued, see Estep v. United States, 327 U.S. 114, 123 (1946), and the treatment there of Falbo v. United States, 320 U.S. 549 (1944).

30 See 75 HARv. L. REv. 1222, 1223 (1962). The court later denied, however, without explanation, that the decision is constitutionally required, In re Turner, 309 F.2d 69, 72 (2d Cir. 1962), reciting only that "the result reached was inherent in the statutory scheme."

31 However, where the statutory scheme is such as to enlist the ultimate aid of enforcement courts, any duty to provide review implied from statute is a constitutional duty also: "[J]urisdiction always is jurisdiction only to decide constitutionally." Hart, supra note 11, at 1402.

Of course it can be argued that issuance of the subpoena itself constitutes extra-judicial governmental coercion. In such a case the Supreme Court has held that the courts can provide review apart from the constitutional requirement that bids them do so when acting as enforcement agencies. Thus in United States v. ICC, 337 U.S. 426 (1949), the Court in construing a silent statute observed that the act's "careful provision for judicial protection 
course, the method of review adopted should be the one involving the minimum interference with the statutory scheme.32 The procedure suggested by Oklahoma Operating Co. v. Love and detailed in Part IV of this comment, rather than the injunction utilized in Colton and detailed in Part $I$, seems to involve the minimum of interference.

The reasoning of the Colton court that the existence of penalty provisions necessitates providing prior opportunity to question validity, if accepted, squarely presents a question as to the best procedure for providing such a prior challenge. Four alternative methods may be proposed. First, as in Colton, the principle of Ex parte Young may be invoked to enjoin or quash the subpoena. Second, the injunctive procedure requirement of irreparable injury may be dispensed with by recourse to the declaratory judgment statute. Third, a colorable doubt as to the validity of the subpoena may be treated as defeating the exaction of penalties for noncompliance with a summons found valid. Fourth, recourse may be had to the procedure utilized in Oklahoma Operating Co. v. Love by enjoining the collection of penalties when an enforcement proceeding has been instituted and the reasons for noncompliance are reasonable. Each of these four approaches satisfies conflicting interests in the law to varying degrees. On one hand are the basic demands of justice and fair play to the subpoenaed witness which find expression in constitutional principles. On the other is the public interest in efficient public administration both to secure the benefits of statutory policies and to prevent delay in the courts. ${ }^{33}$

\section{Quashing of THE Subpoena}

The principle of Ex parte Young arose from a derivative suit by stockholders in a railroad company to enjoin the company's observance of rate schedules for intrastate railroad operation and to enjoin the state attorney general per-

of railroads against improper Commission awards argues against interpretation of the same section to deny shippers any judicial review whatever." Id. at 435 . This argument from the statutory scheme would appear similar to that made by the Second Circuit in Colton.

A three-judge dissenting opinion (per Frankfurter, J.), however, took the view that "unless Congress has chosen to give the courts oversight of a determination by the Commission, the courts have not the power of oversight where, as here, the Constitution does not require it." Id. at 449 . The future willingness of the courts to provide remedies beyond those constitutionally required will depend on their views as to the proper functions of legislature and judiciary, that is, on their willingness to exercise jurisdiction not explicitly conferred by statute. Cf. note 22 supra. Compare 4 Davis $\$ 28.09$.

${ }^{32}$ See generally Brandeis' concurring opinion in Ashwander v. TVA, 297 U.S. 288, 341 (1936); cf. 4 DAvis 93: "The Court's technique for leaving the constitutional question open is simply to review to the extent that the Constitution might require review, no matter how clear the statute may be in cutting off review."

${ }^{33}$ See, e.g., In re Magnus, Mabee \& Reynard, Inc., Docket No. 27813, 2d Cir., Dec. 6, 1962 , where, due to delays resulting from appellants' efforts to avoid compliance with a summons issued by the IRS, the government was forced to secure an indictment against the taxpayers before the summons could be enforced in order to prevent the statute of limitations on criminal prosectuions from running. 
sonally ${ }^{34}$ from enforcing the schedules. Suit was brought on the grounds that the rates were so low as to be confiscatory and that the penalties for noncompliance with the schedules were so severe as to preclude effective legal challenge of the schedules. The Supreme Court held that the district court had jurisdiction to enjoin the threatened enforcement of the schedules since the penalties for noncompliance were so harsh as to force railroads to comply rather than risk unsuccessful challenge. Thus the penalties constituted a denial of due process and were unconstitutional on their face regardless of the validity of the schedules themselves.

In a federal context the principle has been invoked to accord equity courts jurisdiction to provide methods of review thereby avoiding the need to declare penalty provisions in federal statutes unconstitutional. Thus in Estep v. United States, 35 the Court construed the section of the Selective Training and Service Act of 1940 providing that the decision of local boards is "final" to mean only that the customary scope of judicial review was to be restricted, and held that a limited review sufficient to invalidate sham proceedings might still be allowed. By denying that Congress had meant what its words said, the Court was able to avoid declaring unconstitutional the classification system created by the Act. However, the federal courts are bound by state construction of state law and are less free to provide non-statutory remedies for review of state administrative action as alternatives to declarations of unconstitutionality where review is required and is not provided by statute. For a "review of state procedure by a federal court, proceeds in terms of due process rather than separation of powers." 36

The case of Ex parte Young distinguished enactments whose validity depends "upon the existence of a fact which can be determined only after investigation of a very sophisticated and technical character...," where equity might intervene, from legislation requiring no such investigation and over which the jurisdiction of the legislature is complete, where equity will not intervene. 37 Thus, the rule of the case is not generally available to challenge a statute establishing an ordinary criminal offense. 38 The Court also observed that "it is doubtless true that the State may impose penalties, such as will tend

34 In Ex parte Young, the defendant attorney general had threatened suit. For a view that the existence of the statute alone would have constituted the requisite threat to justify judicial intervention, see Borchard, supra note 29; Note, 50 Y ALE L.J. 1278 (1941); cf. note 54 infra.

35327 U.S. 114 (1946).

36 JafFe \& Nathanson, Administrative Law 905 (2d ed. 1961).

37209 U.S. at 148. This test was adopted in United States v. Clyde S.S. Co., 36 F.2d 691, 694 (2d Cir. 1929).

38 Douglas v. Jeanette, 319 U.S. 157 (1943); Whisler v. City of West Plains, 137 F.2d 938 (8th Cir. 1943); Spence v. Cole, 137 F.2d 71 (4th Cir. 1943); see also Borchard, supra note 29 . 
to compel obedience to its mandates by all. ..."39 Even extreme or cumulative penalties are not improper per se: They are unconstitutional when imposed simply to prevent contest of the validity of the statute.40

It has been suggested that the equitable jurisdiction recognized by Ex parte Young exists only in situations like rate-reduction cases where, by complying with the schedules "pending judicial contest of the validity of the order, the contestant would, in case of success, nevertheless suffer confiscation and unrecoverable loss of property through having collected during the period of contest only the unlawfully reduced rate."41 It has also been suggested that the basis of equitable jurisdiction is the threat of penalties and private damage suits arising from failure to comply while good faith doubt exists as to validity. 42

If equity would intervene only in those cases where compliance itself ultimately presents as great a threat as that immediately presented by the noncompliance penalties, then the petititioner in Colton would probably be without standing to seek judicial intervention. The injury to his reputation and his capacity to deal with his clients should he comply is real but seems too indirect.43 Even if equity will intervene whenever an order can be tested only at the risk of substantial penalties, it may still be doubted that the petitioner in Colton was confronted with any substantial risk.

The Colton court distinguishes the threat to the noncomplying witness posed by the subpoenas of the IRS from those of the Civil Aeronautics Board. The distinction, if meaningful, is not that the $\mathrm{CAB}$ lacks direct sanction for noncompliance with its process, for the $C A B$ and the IRS have virtually

39209 U.S. at 146, quoting Cotting v. Kansas City Stock Yards Co., 318 U.S. 79, 102 (1901). See United States v. Clyde S.S. Co., 36 F.2d 691, 695 (2d Cir. 1929), where the court observes that a penalty of $\$ 500$ a day does not seem confiscatory since a small penalty would be no inducement to compliance.

40209 U.S. at 147; Cotting v. Kansas City Stock Yards Co., supra note 39, at 102. The principle of Ex parte Young has often been applied. It is not impossible, however, to conceive of a statute so drafted as to permit an initial constitutional test free of the threat of penalty, thus giving substance to the dictum that extreme penalties are not improper per se. The fact, however, that the validity of a statute might be determined in a collateral proceeding (like the derivative suit in Ex parte Young itself) would seem insufficient to vindicate a statute with extreme penalties.

41 Bartlett Frazier Co. v. Hyde, 65 F.2d 350, 353 (7th Cir. 1933). This is not, however, an argument for judicial intervention where the statutory penalties are not extreme or cumulative. Compare Oklahoma Operating Co. v. Love, 252 U.S. 331, 336-37 (1920), which emphasizes the burden of the penalties, not the costs of compliance.

42 Central Ky. Natural Gas Co. v. Railroad Comm'n of Ky., 37 F.2d 938 (E.D. Ky. 1930); see Natural Gas Pipeline Co. v. Slattery, 302 U.S. 300 (1937); Oklahoma Operating Co. v. Love, supra note 41; FTC v. Millers' Nat'l Fed'n, 23 F.2d 968 (D.C. Cir. 1927).

43 See Guaranty Underwriters, Inc. v. Johnson, 133 F.2d 54 (5th Cir. 1943). But see Bank of America v. Douglas, 105 F.2d 100 (D.C. Cir. 1939). 
identical powers, 44 but that it more rarely exercises the power that it does possess. 45 The main reliance of the administrative agencies has been upon judicial enforcement of subpoenas: 46 Seldom, if ever, do the agencies seek the imposition of direct criminal penalties for noncompliance. ${ }^{47}$ And even judicial enforcement is resorted to relatively infrequently. 48 The IRS, considering the bulk of its work, hardly seems to depart from this pattern. Of the forty-five reported cases that have arisen over twenty years enforcement of IRS subpoenas, 49 all but one 50 arose as civil proceedings for judicial enforcement. Even if criminal penalties are considered to fall within the ambit of Ex parte Young, it seems absurd to consider the petitioner in Colton under a threat of prosecution so immediate as to support equitable jurisdiction to intervene. 51

44 Compare INT. REv. CoDE of $1954 \$ 7210$ (Any person who "neglects to appear or to produce such books ... or other papers, shall, upon conviction thereof ..." be subject to fine or imprisonment or both.), with Federal Aviation Act of 1958, 72 Stat. 784 (1958), 49 U.S.C. \$1472(g) (1958), set out in text accompanying note 14 supra.

45 In the more than twenty years since the study by the United States Attorney General's Committee on Administrative Procedure, only one case has been reported as arising under the CAA-CAB-FAA subpoena power and that was a civil proceeding for judicial enforcement, CAB v. Hermann, 353 U.S. 322 (1957).

461 Davis $\$ 3.11$; Comment, supra note 3, at 1541.

47 E.g., "except for one indictment in 1935 against a person who died before trial, and an information filed in 1958 against a fugitive who failed to respond to an order to show cause in a subpoena-enforcement proceeding, the Commission has never attempted to enforce any of these provisions. And this is typical of other agencies as well." 3 Loss, op. cit. supra note 3, at 1965. See UNITED STATES ATTORNEY GENERAL's CoMmTrTEE ON ADMINISTRATIVE PROCEDURE, MONOGRAPHS (1940), detailing the operation of the several agencies.

48 See, e.g., United States Atrorney General's Committee on Administrative ProCEDURE, MONOGRAPH No. 1, at 25 (1940) (administration of Walsh-Healy Act); MONOGRAPH No. 3, at 47-48 (1940) (FCC); MoNOGRAPH No. 18, at 42-43 (1940) (NLRB). Conclusions are reported in the Committee's report, Administrative Procedure in Governmental Agencies, S. Doc. No. 8, 77th Cong., 1st Sess. 414 (1941). Some agencies make almost no use of the subpoena power itself. See MoNograph No. 2, at 50-51 (1939) (VA); MONOGRAPH No. 12, at 70 (1940) (Wage \& Hour Division of Dep't of Labor); MONOGRAPH No. 8, at 33 (1940) (Railroad Retirement Board).

49 Significantly, INT. REv. CODE OF 1954 \$ 7604(b), providing for attachment as for contempt is consistently treated as a procedure for the judicial enforcement of IRS subpoenas rather than as a direct sanction for noncompliance as suggested in Colton, 291 F.2d at 48990. See note 4 supra.

50 United States v. Becker, 259 F.2d 869 (2d Cir. 1958), cert. denied, 358 U.S. 929 (1959).

51 The reports are generally barren of details but there seems to be nothing in the language of the subpoena to make the witness apprehensive of prosecution. The subpoena set out in International Commodities Corp. v. IRS, 224 F.2d 882, 883 (2d Cir. 1955), warns only that "failure to comply with this summons will render you liable to proceedings in the district court of the United States for the district in which you reside, to compel your attendance, testimony, and production of books, etc." But see Natural Gas Pipeline Co. v. Slattery, 302 U.S. 300 (1937); FTC v. Millers' Nat'l Fed'n, 23 F.2d 968 (D.C. Cir. 1927); S \& W Cafeteria of Tenn. v. Aird, 60 F. Supp. 599 (E.D. Tenn. 1945).

The reports, however, are scant indication of the actual formal and informal practices of the agencies. If petitioner could establish that agency practice did in fact create a signif- 


\section{Relief By Declaratory Judgment}

If a threat can be said to face the objecting witness it is the latent power of the subpoenaing agency to seek the imposition of criminal sanctions. Although there is not such an immediate threat of irremediable injury as would support a suit for injunction, some commentators 52 have suggested that the very existence of a statute imposing penal sanctions creates a sufficient threat to provide the "case of actual controversy" necessary to support a proceeding for a declaratory judgment. ${ }^{53} \mathrm{An}$ attempt has been made to qualify this view by making a dubious distinction between statutes that vest discretion in prosecutors and statutes that are said not to do so. 54 In fact, in nearly all cases where extraordinary relief has been granted, courts have at least recited a threat of enforcement. 55 FTC v. Claire Furnace Co. ${ }^{56}$ dismissed for want of jurisdiction a suit to enjoin the enforcement of Commission orders to produce certain detailed information. The Court argued that since the Commission itself could

cant fear of prosecution although prosecution had not been explicitly threatened, then declaratory relief should be available. In this context the disparity in agency practice, little discussed here, is critical. Compare Hall v. Lemke, Trade REg. REP. (1962 Trade Case.) T70,338 (N.D. Ill. May 7, 1962) with Brody v. United States, 243 Fed. 378 (1st Cir.), cert. denied, 354 U.S. 923 (1957). If prosecution actually were presently threatened, an injunction probably would be available. Hall v. Lemke, supra.

52 Borchard, supra note 29; Note, 50 YALE L.J. 1278 (1941). On tipeness problems generally, see 3 DAVIS $\$ \$ 21.05-06$, and on the related exhaustion problem, see 3 DAVIs $\$ 20.03$. See also Developments in the Law-Declaratory Judgments, 62 HARv. L. Rev. 787 (1949), and the realistic standard of "relative certainty" there developed.

53 Mr. Justice Frankfurter's dictum in Colegrove v. Green, 328 U.S. 549, 551-52 (1946), would indicate that a proceeding for declaratory relief is appropriate only where the controversy would be justiciable as a suit for an injunction. See also, e.g., Macauley v. Waterman S.S. Corp., 327 U.S. 540, 545 n.4 (1946). The better view would seem to be that the standards are not the same. Note, 56 Yale L.J. 139 (1946); Note, supra note 52. The controversy, of course, must be real and immediate. Public Serv. Comm'n of Utah v. Wycoff Co., 344 U.S. 237 (1952); Eccles v. Peoples' Bank of Lakewood, 333 U.S. 426 (1948); Ashwander v. TVA, 297 U.S. 288 (1936); see generally Borchard, The Next Step Beyond Equity-The Declaratory Action, 13 U. CHI. L. REv. 145 (1946); Developments, supra note 52; Comment, 62 ColUM. L. REv. 206 (1962). 28 U.S.C. $\$ 2201$ (1958) provides that a declaration of rights is available "whether or not further relief is or could be sought." (Emphasis added.)

54 Note, supra note 52, at 1284. The note attacks the reasoning developed in Ex parte La Prade, 289 U.S. 444 (1933), (criticized, Note, 43 YaIE L.J. 500 (1934)), and Southern Pacific Co. v. Conway, 115 F.2d 746 (9th Cir. 1940), and preserved in FED. R. Crv. P. 25(d) making official threat of enforcement a requisite element of a justiciable challenge of a criminal statute. The leading case of Ex parte Young presumed, without discussion, the necessity of a threat of enforcement.

55 See 3 DAVIs $§ 21.05$. In particular, see Evers v. Dwyer, 358 U.S. 202 (1958).

56274 U.S. 160 (1927). Suit for injunction here, like the motion to vacate in Colton, is used to effect a declaration of rights. Procedurally, the witness would prefer the ex parte motion to vacate the subpoena to an adversary declaratory judgment proceeding and would prefer the declaratory judgment to an injunction since irremediable injury need not be shown in the former case and there are other procedural and calendar advantages. See Borchard, supra note 53 , at 158 . 
impose no penalties but was empowered only to ask the Attorney General to seek judicial enforcement or to institute an action to recover penalties for noncompliance, a suit in equity was premature until the Attorney General at his discretion 57 instituted either proceeding. FTC v. Maynard Coal Co.58 extended the rule by holding that suit to enjoin the enforcement of Commission subpoenas is premature following the mere filing by the Commission of notice of default, where penalties do not begin to run until thirty days after the notice is filed.

But the Second Circuit in United States v. St. Regis Paper Co. ${ }^{59}$ suggested that the passage of the declaratory judgment statute nullified the rule requiring threat of prosecution. ${ }^{60}$ The court questioned the rule itself, observing that "if judicial review were in fact limited to enforcement proceedings instituted by the Commission, and a daily forfeiture were collected for a failure to comply, the procedure might not meet the established standards of due process." 61 It held that jurisdiction will lie under the declaratory judgment statute to test the demand of an administrative agency for special reports. 62 "The respondent bringing such an action would be effectively denied judicial review if he is permitted no forum in which to challenge the validity and scope of the agency's order; his injury, therefore, is immediate enough to warrant judicial intervention even if the agency is not prepared to institute court proceedings to achieve compliance."63 And only if such review is available can the penalty provisions withstand attack as a denial of due process. 64

On certiorari the Supreme Court, 65 however, declined to go so far. It distin-

57 Federal Trade Comm'n Act, 38 Stat. 723 (1914), 15 U.S.C. $\$ 50$ (1958), however, declares that "it shall be the duty of the various United States attorneys, under the direction of the Attorney General of the United States, to prosecute for the recovery of forfeitures." Claire Furnace discussed the recovery of forfeitures as a remedial civil remedy rather than a punitive criminal penalty, FTC v. Millers' Nat'l Fed'n, 23 F.2d 968 (D.C. Cir. 1927), but in the imposition of money penalties, at least, forfeitures and flat fines are essentially similar. And there is no distinction in the Act between the acts from which liability for civil or for criminal sanctions arises.

5822 F.2d 873 (D.C. Cir. 1927).

59285 F.2d 607 (2d Cir.), affirming in part and reversing in part 181 F. Supp. 862 (S.D.N.Y. 1960).

60285 F.2d at 615 . Ironically, recovery of penalty forfeitures was allowed on the ground that since there was opportunity to challenge the Commission order before penalties for noncompliance attached, it was fair to penalize a noncomplying witness who awaited mandamus proceedings to make his challenge. But see concurring opinion of Friendly, J., id. at 616.

61 Id. at 615.

$62 \mathrm{Ibid}$. The court expressly reserved judgment on whether the order to produce retained file copies was a subpoena within the meaning of $\$ 6(\mathrm{c})$ of the Administrative Procedure Act, 60 Stat. 240 (1946), 5 U.S.C. $\$ 1005$ (c) (1958). 285 F.2d at 615. But it was so treated in the district court, 181 F. Supp. at 868; Brief for Petitioner, p. 19, St. Regis Paper Co. v. United States, 368 U.S. 208 (1961), and is so treated in this discussion.

63285 F.2d at 615.

64 Id. at 616.

65 St. Regis Paper Co. v. United States, 368 U.S. 208 (1961). 
guished Claire Furnace and possibly Maynard Coal observing that, in the former case, "the Commission ... had not issued any notice of default on the orders, as was done here, nor had the orders been forwarded to the Attorney General for enforcement." 66 The Court remarked only that a proceeding for declaratory judgment "appears sufficient to meet petitioner's needs." 67 However, a declaration of rights at some time after the notice of default could not meet the needs of the individual subject to criminal penalties 68 and also, if forthcoming only after the Commission had forwarded the orders to the Attorney General for enforcement, would not meet the needs of the corporation subject to civil forfeitures.

\section{Good Faith Noncompliance as Mitigation}

The suggestion that penal statutes providing penalties for noncompliance should be strictly construed ${ }^{69}$ so as to require proof of lack of good faith as an element of the offense 70 does not seem likely to afford the individual witness any protection. Even those statutes requiring that criminal noncompliance be "willful" have not always been construed to permit a good faith challenge to go without penalty. 71 FPC v. Metropolitan Edison Co.72 declares only that

66 Id. at 226. The distinction creates new uncertainties. Claire Furnace held that until the Attorney General acted there could be no justiciable controversy. 274 U.S. at 174. By the shift in the focus of attention from the Attorney General's to the Commission's discretion, the status of Claire Furnace is cast in doubt. While the Court still appears to hold that issuance of a notice of default by the Commission is a necessary condition to declaratory relief, whether it is a sufficient condition is unclear.

67368 U.S. at 227.

68 It is the fact of noncompliance and not the timing of later judicial proceedings that places the witness in jeopardy. Brief for United States, p. 58, St. Regis Paper Co. v. United States, 368 U.S. 208 (1961). If the declaration is sought after noncompliance it offers no protection and is probably denied, in any event, on the reasoning of Douglas v. City of Jeanette, 319 U.S. 157 (1943). And if declaration is sought before the return date it is probably open to attack for prematurity. See United Pub. Workers v. Mitchell, 330 U.S. 75 (1947). Similarly the stay suggested by the Supreme Court in St. Regis, 368 U.S. at 226, may protect the defaulting corporation from the running of forfeitures but is of no protection to the individual subject to flat criminal penalties.

69 St. Regis Paper Co. v. United States, 368 U.S. 208, 230 (1961) (Black, J., dissenting and affirming the view of the district court, 181 F. Supp. 862, 869 (1960)); Flemming v. Arsenal Bldg. Corp., 38 F. Supp. 675 (S.D.N.Y. 1940). See United States v. National Biscuit Co, 25 F. Supp. 329 (S.D.N.Y. 1938).

70 See 368 U.S. at 230.

71 But cf. Reisman v. Caplin, No. 16690, D.C. Cir., Feb. 17, 1963, p. 7 n.4: "The position of the Assistant United States Attorney on this appeal is that a criminal prosecution under Section 7210 of the Revenue Code, referred to in Application of Colton ... would not follow from a good faith refusal to comply with a revenue summons."

An exception is the Securities Exchange Act of 1934, 48 Stat. 899 (1934), 15 U.S.C. $\S 78 u(c)$ (1958), which has been unequivocally construed to admit good faith noncompliance as a defense. Guaranty Underwriters, Inc. v. Johnson, 133 F.2d 54, 56 (5th Cir. 1943). That Act, however, is unique in that it requires that criminal noncompliance be "without just cause"-language found in only three other acts: Public Utility Holding Co. Act of 1935, 49 Stat. 831 (1935), 15 U.S.C. $\$ 79$ (d) (1958); Investment Co. Act of 1940, 54 Stat. 842 (1940), 
'the qualification that the refusal be 'willful' fully protects one whose refusal is made in good faith and upor grounds which entitle him to the judgment of the court before obedience is compelled." 73 This language may mean nothing more than express recognition that the invalidity of the subpoena will be a defense to criminal action for noncompliance. ${ }^{74}$ Although it is a misdemeanor "willfully" to default when summoned by the authority of Congress, 75 "no moral turpitude is involved. Intentional violation is sufficient to constitute guilt."76 "A witness may exercise his privilege of refusing to answer questions and submit to a court the correctness of his judgment in so doing, but in the event he is mistaken as to the law it is no defense, for he is bound rightly to construe the statute."'77

There is only one instance, other than the special circumstances of the Guaranty Underwriters case, 78 in which good faith noncompliance has been recognized as a bar to criminal proceedings. A witness declined to comply with a congressional subpoena on the advice of counsel on a question of law as to which the witness was in bona fide doubt and as to which the law was,

15 U.S.C. $\$ 80 \mathrm{a}-41$ (c) (1958); Investment Advisors Act of 1940, 54 Stat. 853 (1940), 15 U.S.C. $\$ 80 \mathrm{~b}-9$ (c) (1958). All are administered by the SEC which seldom exercises its direct sanctions. See note 47 supra.

. 72365 U.S. 375 (1938). $\quad 73$ Id. at 387. (Emphasis added.)

74 It is, for instance, no defense to criminal contempt proceedings for violation of an injunction granted by a court of competent jurisdiction that the injunction was improvidently granted and struck down on review. It is, however, a defense that the enjoining court was without jurisdiction. See Cox, The Void Order and the Duty to Obey, 16 U. CHI. L. REv. 86 (1948).

Estep v. United States, 327 U.S. 114 (1946), and Yakus v. United States, 321 U.S. 414 (1944), go no further than to make availability of the defense of invalidity a constitutional necessity. Estep permits restriction of the review of validity to narrow grounds and appears to require only that the order not be based on a sham proceeding. Yakus permitted restriction of the trial of the issue of validity to the Emergency Court of Appeals, a forum necessarily different from that in which the criminal prosecution for noncompliance would be brought, and limited review there to the ninety days immediately following promulgation of the objected to-order. It should be noted, however, that the results in both cases derive some support from the war power. But $c f$. Cobbledick v. United States, 309 U.S. 323, 328 (1940): "Whatever right [the subpoenee] may have requires no further protection ... than that afforded by the district court until the witness chooses to disobey and is committed for contempt." (Emphasis added.) See note 23 supra.

7552 Stat. 942 (1938), 2 U.S.C. $\$ 192$ (1958): "Every person who having been summoned as a witness by the authority of either House of Congress . . . willfully makes default or who, having appeared, refuses to answer any question pertinent to the question under inquiry, shall be deemed guilty of a misdemeanor. ..." punishable by fine or imprisonment.

76 Sinclair v. United States, 279 U.S. 263, 299 (1929). See Fields v. United States, 164 F.2d 97 (D.C. Cir. 1947), ecrt. denied, 332 U.S. 851 (1948); Townsend v. United States, 95 F.2d 352 (D.C. Cir.), cert. denied, 303 U.S. 664 (1938).

77 Townsend v. United States, 95 F.2d at 361.

78 Guaranty Underwriters, Inc. v. Johnson, 133 F.2d 54 (5th Cir. 1943). See note 71 supra. Compare Columbia Broadcasting System v. United States, 316 U.S. 407 (1942), where an agency minute providing immunity from prosecution for an initial violation to test a new rule was held insufficient to justify denial of an injunction against its enforcement. See 3 Davis 151-55. 
in fact, uncertain. ${ }^{79}$ The Second Circuit in St. Regis, however, refused to read into the Federal Trade Commission Act even this limited restriction on liability. The petitioner company had declined to produce retained file copies of census reports on the ground that the reports were confidential. 80 The objection was made in good faith and on reasonable grounds on the basis of doubt as to a question that had never been decided by the Supreme Court and on which there was only a single circuit court opinion-an opinion that favored the petitioner's view.81 Still the court said "that the respondent's recalcitrance was caused by a wrong guess on a disputed issue of law does not prevent it from being held to 'lawful consequences attached to the refusal.' "82 The only mitigation of the "statute's absolute and imperative terms" that the court suggested was that accorded to "a single oversight or an honest mistake in a good faith attempt to comply with the Commission's order. ..."83

\section{Injunction of Criminal Penalties Where There Has BeEN Good Farth Noncompliance}

Upon government institution of a criminal action based on noncompliance, the witness probably may bring suit to enjoin the imposition of penalties, thus supplying himself with protection where he acted in good faith. The petitioner in the well-known case of Oklahoma Operating Co. v. Love84 challenged the rate schedules controlling its operation. The Supreme Court held that the petitioner was entitled to a temporary injunction restraining the imposition of the penalties for noncompliance with the rate schedules pending hearing

79 Townsend v. United States, 95 F.2d 352, 359 (D.C. Cir.) (dictum), cert. denied, 303 U.S. 664 (1938). The defense was said to arise from Murdock v. United States, 290 U.S. 389 (1933), which construes a section of the Internal Revenue Statute relating to filing of tax returns. But the Court there looked less to the uncertainty of the law and petitioner's doubts, 290 U.S. at 396 , than to the context of the statute itself, concluding that "willfully" denoted morally culpable behavior. Id. at 395-96.

${ }^{80}$ Section 9(a) of the Census Act, 68 Stat. 1013 (1954), 13 U.S.C. $\$ 9$ (a)(1958), provides that neither the Secretary of Commerce nor any officer or employee of the Department of Commerce or of any bureau or agency thereof may "permit anyone other than the sworn officers and employees of the Department or bureau or agency thereof to examine the individual reports." See 36 OPS. ATT'Y GEN. 362 (1930). The agency contended that this prohibition did not prevent demand of petitioner company's records and analogized to the income taxpayer's retained file copies of returns which are subject to subpoena. United States v. O'Mara, 122 F. Supp. 399 (D.D.C. 1954).

81 FTC v. Dilger, 276 F.2d 739 (7th Cir. 1960), rejected the analogy to retained file copies of income tax returns and held the census reports confidential. Ironically, after the Supreme Court rejected Dilger in St. Regis, Congress amended $\$$ 9(a) of the Census Act to provide that no agency or officer of the government shall require the production of retained records of census reports and that "copies of census reports which have been so retained shall be immune from legal process, and shall not, without the consent of the individual or establishment concerned, be admitted as evidence or used for any purpose in any action, suit or other judicial or administrative proceeding." 76 Stat. 922 (1962), 13 U.S.C. \$9(a) (1962).
82285 F.2d at 614.
83 Ibid.

84252 U.S. 331 (1920), 18 Mick. L. Rev. 804 (1920). 
of the cause and that "if upon final hearing the maximum rates fixed should be found not to be confiscatory, a permanent injunction should, nevertheless issue to restrain enforcement of penalties accrued pendente lite, provided that it also be found that the plaintiff had reasonable ground to contest them as being confiscatory." 85

Thus the witness is not without procedures, consistent with the public interest in efficient public administration, by which to protect himself.86 Although it can be recommended that section 10(d) of the Administrative Procedure Act ${ }^{87}$ be amended to articulate clearly the availability of such injunctive relief and thereby minimize conflicts in practice between the circuits, there is adequate foundation for seeking such an injunction even without statutory revision. Indeed, injunction of the imposition of penalties is probably presently available under section 10 (d) which provides that, to avoid irreparable injury, the court may issue "all necessary and appropriate process ... to preserve status or rights" pending review.

Professor Paul Freund has suggested by implication that such injunctive relief may presently be limited in availability to cases involving continuing forfeitures or orders imposed upon respondents under a continuing duty to serve or its equivalent. 88 In Highland Farms Dairy Co. v. Agnew, 89 however, a district court declined to enjoin the operation of a newly created milk

85252 U.S. at 338 . The Court held the penalty provisions of the state statute void on their face, following Ex parte Young. See p. 512 supra. However, the injunction of enforcement of penalties was independent of this holding, since a subsequent amendment to the statute provided adequate review and the Supreme Court, instead of leaving petitioner to his state remedy, allowed the district court to retain jurisdiction to review the constitutionality of the rates. It was in this context that the injunction against enforcement of penalties was granted.

${ }^{86}$ The procedures previously discussed would place a serious burden upon the administrative process not justified by any threat to the witness. See Flemming v. Arsenal Bldg. Corp., 38 F. Supp. 675, 677 (S.D.N.Y. 1940). It would be a cruel irony if the mere existence of the power to seek direct sanctions for noncompliance justified judicial intervention. The existence of the criminal provisions is an aid in obtaining compliance, even though penalties are rarely sought. See 1 DAvIs $\$ 2.12$ n.1. The presence of strong tools to encourage promptness should not be made grounds for imposing delay on the administrative process. And if the agency were compelled to prove bad faith when it chose to use the criminal provisions, the effectiveness of the sanction might be seriously reduced. See 3 Loss, SECURITIES REGULATION 1965 (1961).

8760 Stat. 243 (1946), 5 U.S.C. $\$ 1009$ (d) (1958).

88 FReUnd, The SUPREME COURT OF THE UNITED STATES 65 (1961): "If [the] . . constitutional challenge were a reasonable one, though finally rejected, might it not be possible to enjoin prosecution for the interim violations in the interest of removing a clog on the process of constitutional adjudication? Something of the kind has been done where a public utility has no means of challenging an order other than violation and exposure to multiple penalties. Of course the utility is under a duty to serve... The case of the distributor of leaflets is relegated to a lower level unless it is recognized that the duty to serve may find an equivalent in the public interest in freedom of expression in marginal cases while the validity of a restraint is being tested."

89 16 F. Supp. 575 (E.D. Va. 1936). 
commission where one of the claims raised was that the penalties for noncompliance with the subpoenas issued by the commission were so severe as to constitute a denial of due process. Noncompliance was punishable by fines of up to one hundred dollars or by imprisonment for up to ninety days for each offense. The court reasoned that "the procedure to be followed with regard to such penalties, when the enforcement of the orders of $a[n]$. . . administrative body is resisted on constitutional grounds, is suggested ... in Oklahoma Operating Co. v. Love...."90 Other courts have also indicated by way of dictum that the power to enjoin the collection of penalties is a general equity power. 91

It will be admitted that "colorable doubt," "reasonable ground" and "good faith" are only vaguely defined terms and that the witness who seeks in good faith to challenge a subpoena served upon him does not do so without some risk. But there are uncertainties in much of the law and the risk that such a witness assumes is slight. A too precise definition of good faith may well, unfortunately, only encourage bad faith. It might also be contended that conviction for noncompliance, even if no penalty is imposed, imposes a social stigma that the morally blameless should not be compelled to bear and that might itself coerce compliance and thus work a denial of due process. However, it is yet uncertain in the law even that the risk of criminal penalties following prosecution will render justiciable a suit for the injunction of prosecution pending the test of a statute of questionable constitutionality. ${ }^{92}$ No cases raise to the level of justiciability, let alone denial of due process, the possible social stigma of criminal proceedings per se, where no risk of penalty is involved.

Allowance of suits brought after noncompliance to enjoin the imposition of penalties would afford to the aggrieved witness the opportunity to be heard in court without practical fear of sanctions for a reasonable but unsuccessful attack upon the process of an administrative agency. While one trial is generally to be preferred to two, such a procedure actually works to ease the burdens on the witness, the agency and the courts. It does away with the need for prosecution and defense of suits brought to prevent the possible infliction of criminal sanctions seldom utilized by agencies, and relieves courts of suits based on remote hypotheses. The proposed procedure would preserve to the agency its sanctions against contumacy or dilatory conduct, sanctions which would be vitiated if judicial intervention before violation were allowed, or if the burden of pressing the issue of good faith were not placed upon the witness.

$90 \mathrm{Id}$. at 585. Cf. Ohio Custom Garment v. Lind, 13 F. Supp. 533 (S.D. Ohio 1936). See also Yakus v. United States, 321 U.S. 414, 437-38 (1944).

91 Otoe County Nat'l Bank v. Delaney, 88 F.2d 238, 243 (8th Cir. 1937); Connecticut Fire Ins. Co. v. McNeil, 35 F.2d 675, 676 (6th Cir. 1929).

92 See Comment, Threat of Enforcement-Prerequisite of a Justiciable Controversy, 61 Colum. L. REv. 106 (1962). Professor Davis has urged a broader standard of review. See 3 Davis 141-68. 